\title{
Data Jenis-jenis Kupu-kupu Di Lingkungan Perumahan Bukit Kalibagor
}

\author{
Fitri Rahmawati ${ }^{\text {a }}$, Bagas Prakoso ${ }^{\text {b }}$ \\ ${ }^{\mathrm{a}, \mathrm{b}}$ Universitas Ma'arif Nahdlatul Ulama Kebumen, Indonesia \\ $\underline{\text { rahmawatif3@gmail.com }}^{\text {a }}, \underline{\text { bgsprks@gmail.com }}^{\text {b }}$
}

\begin{abstract}
Abstrak
Kupu-kupu merupakan bagian dari kekayaan hayati yang harus dijaga kelestariannya. Kupu-kupu memiliki nilai penting bagi manusia maupun lingkungan antara lain: nilai ekologi, estetika, pendidikan, endemis, konservasi dan budaya. Kupu-kupu adalah salah satu jenis serangga yang berasal dari ordo lepidotera yakni serangga yang sayapnya ditutupi oleh sisik, dan memiliki peranan yang sangat penting dalam mempertahankan ekosistem. Penyebaran geografi yang baik dan keanekaragaman kupu-kupu dapat memberikan informasi yang baik dalam studi lingkungan sebagai indikator lingkungan, serta perubahan yang mungkin terjadi. Kupu-kupu juga memberi andil yang sangat berarti dalam mempertahankan keseimbangan alam dengan bertindak sebagai penyerbuk pada bunga bersama hewan penyerbuk lainnya. Kupu-kupu juga merupakan serangga yang keberadaannya ditentukan oleh kemampuan distribusi dan adaptasi terhadap faktor lingkungan. Faktor yang sangat berperan penting terhadap keberadaan kupukupu adalah tumbuhan. Tumbuhan digunakan kupu-kupu sebagai tumbuhan inang dan sumber pakan. Keanekaragaman kupu-kupu juga dipengaruhi oleh faktor abiotik. Beberapa faktor abiotik yang mempengaruhi kehidupan kupu-kupu, antara lain: suhu, kelembaban udara, musim, dan kecepatan angin. Bagaimana jenis-jenis kupu-kupu di lingkungan perumahan Bukit Kalibagor Indah belum pernah diteliti dan dipublikasikan mengingat pada saat ini jenis kupu-kupu di setiap ekosistem memiliki macam spesies yang berbeda-beda. Penelitian ini bertujuan untuk mengetahui jenis kupu-kupu di lingkungan Perumahan Bukit Kalibagor Indah. Parameter yang diamati yaitu jenis-jenis kupu-kupu. Sampel di ambil dari lingkungan Perumahan Bukit Kalibagor Indah. Penelitian dilakukan pada bulan April 2021 - bulan Juni 2021 selama 2 Bulan. Penelitian ini dilakukan dengan metode jelajah. Hasil penelitian ditemukan 10 spesies dengan 6 genus dari 48 individu yang termasuk ke dalam 2 famili, yaitu Nympalidae (3 spesies) dan Pieridae ( 7 spesies).
\end{abstract}

Kata kunci : Jenis, Kupu-kupu, Perumahan Bukit Kalibagor Indah

\begin{abstract}
Butterflies are part of the biological wealth that must be preserved. Butterflies have important values for humans and the environment, including: ecological, aesthetic, educational, endemic, conservation and cultural values. Butterflies are one type of insect that comes from the order Lepidotera, namely insects whose wings are covered by scales, and have a very important role in maintaining the ecosystem. Good geographical distribution and diversity of butterflies can provide
\end{abstract}



good information in environmental studies as environmental indicators, as well as changes that may occur. Butterflies also make a very significant contribution in maintaining the balance of nature by acting as pollinators in flowers along with other pollinating animals. Butterflies are also insects whose existence is determined by their distributional ability and adaptation to environmental factors. Factors that play an important role in the existence of butterflies are plants. Plants are used by butterflies as host plants and food sources. Butterfly diversity is also influenced by abiotic factors. Several abiotic factors that affect the life of butterflies, among others: temperature, humidity, season, and wind speed. How the types of butterflies in the residential area of Bukit Kalibagor Indah have never been studied and published considering that currently the types of butterflies in each ecosystem have different species. This study aims to determine the types of butterflies in the Bukit Kalibagor Indah residential area. The parameters observed were the types of butterflies. Samples were taken from the Bukit Kalibagor Indah residential area. The research was conducted in April 2021 - June 2021 for 2 months. This research was conducted using the roaming method. The results of the study found 10 species with 6 genera from 48 individuals belonging to 2 families, namely Nympalidae (3 species) and Pieridae (7 species).

Keywords: Types, Butterflies, Beautiful Kalibagor Hill Housing

\section{Pendahuluan}

Indonesia merupakan salah satu negara yang memiliki biodiversitas tertinggi di dunia. Indonesia menempati posisi kedua setelah Brazil, sehingga dikenal dengan sebutan Megabiodiversity (Yanuar et al, 2011). Salah satu keanekaragaman hayati tertinggi di Indonesia adalah kupu-kupu. Kupu-kupu yang ditemukan di Indonesia sekitar 2.000-2.500 spesies dari 17.500 spesies yang dikenal di seluruh dunia (Leo et al, 2016).

Kupu-kupu yang merupakan salah satu kekayaan hayati yang dimiliki Indonesia dan harus dijaga kelestariannya dari kepunahan maupun penurunan keanekaragaman jenisnya. Kupu-kupu termasuk dalam ordo Lepidoptera, yakni serangga yang sayapnya ditutupi oleh sisik, yang lepas seperti debu pada jari-jari seseorang bila sayapnya dipegang. Saat ini, kupukupu menghadapi ancaman kepunahan yang disebabkan oleh konversi lahan di habitatnya. Keberadaan populasi kupu-kupu pada habitat bergantung pada keanekaragaman inang dan ketersediaan makanan (Koneri dan Maabuat, 2016).

Kupu-kupu memiliki nilai penting bagi manusia maupun lingkungan antara lain, nilai ekonomi, ekologi, estetika, pendidikan, konservasi dan budaya (Lamatoa et. al, 2013). Kehadiran kupu-kupu sebagai insekta penyerbuk membantu memelihara perbanyakan tumbuhan secara alami. Sedangkan keragaman kupu-kupu pada suatu habitat dapat digunakan sebagai indikator kerusakan habitat karena kepekaannya terhadap perubahan lingkungan dan perubahan pola keragaman taxa, serta mudah dikenali baik taksonomi maupun sejarah hidupnya serta mudah ditangkap (Widhiono, 2015).

Menurut Noprin dalam Awinda, (2012) di alam keanekaragaman jenis kupu-kupu berbeda di setiap tempat. Hal ini dipengaruhi oleh banyak faktor diantaranya jenis tanaman, udara yang bersih, dan pencahayaan yang cukup. Kerusakan alam seperti berubahnya fungsi 
areal hutan, sawah, dan perkebunan yang menjadi habitat bagi kupu-kupu, dapat menyebabkan penurunan jumlah maupun jenis kupu-kupu di alam.

Penelitian tentang kupu-kupu sudah banyak dilakukan diberbagai ekosistem. Apriyanti (2004) melakukan penelitian di kawasan Taman Wisata Alam Pananjung, Pangandaran tercatat 32 jenis. Hasil penelitian Arumsari et al., (2013) di kawasan Nusakambangan ditemukan 52 spesies kupu-kupu. Widhiono (2015) hasilnya menunjukan bahwa 32 spesies sangat bergantung pada kondisi habitat hutan asli dan kawasan wisata di Gunung Slamet masih memilki 71 spesies, diversitas kupu-kupu berbeda pada habitat hutan yang berbeda. Keanekaragaman jenis kupu-kupu Famili Nymphalidae ditemukan 13 spesies dan Pieridae sebanyak 2 spesies dikawasan Cirengganis dan padang rumput Cikamal Cagar Alam Pananjung Pangandaran (Lestari, 2018).

Rahmawati (2017) menemukan 60 spesies dengan 38 genus dari 1165 individu, yang termasuk ke dalam 6 famili, yaitu Nympalidae (29 spesies), Papilionidae (11 spesies), Pieridae (9 spesies), Lycanidae (8 spesies), Hesperiidae (1 spesies) dan Riodinidae (1 spesies)di Taman Wisata Alam Pananjung, Pangandaran. Selain itu, Amanda (2019) melakukan penelitian ordo lepidoptera di Perumahan Citra Grand City Kota Palembang ditemukan 8 spesies yaitu Neptis hylas, Junonia orithya, Junonia erigone, Euretema hecabe, Leptosia nina, Appias olferna, Papilio polythes, dan Danaus chrysippus. Kurniawan, et al., (2020) di Habitat Eko-wisata Taman Bunga Merangin Garden Bangko Jambi, menemukan sebanyak 3 famili dari 16 jenis spesies.

Jenis-jenis kupu-kupu yang beragam ditemukan di berbagai tempat di Indonesia, termasuk di lingkungan perumahan penduduk yang masih banyak terdapat tumbuhan dan beberapa area yang dijadikan taman. Salah satunya di Perumahan Bukit Kalibagor Indah Kabupaten Banyumas. Berdasarkan hasil observasi, area ini luasnya 9,5 HA yang meliputi area hijau, taman, sekolah, tempat ibadah, dan berbagai fasilitas-fasilitas lainnya. Oleh karena itu, perlu dilakukan penelitian tentang jenis-jenis kupu-kupu di lingkungan Perumahan Bukit Kalibagor Indah.

\section{Metodologi Penelitian}

Penelitian kupu-kupu dilakukan di lingkungan Perumahan Bukit Kalibagor Indah Pengambilan sampel dari bulan April 2021 - bulan Mei 2021 selama 2 Bulan. Survai kupukupu dilakukan dengan menggunakan metode jelajah dari pukul 08.00-12.00 WIB. Pengambilan data diulang sebanyak 3 kali pengulangan.

Alat yang digunakan pada penelitian ini meliputi insect net, termometer, higrometer, dan camera digital. Insect net digunakan untuk menangkap kupu-kupu. Termometer digunakan untuk mengukur temperatur atau suhu. Higrometer untuk mengukur kelembaban. Bahan yang digunakan dalam penelitian ini yaitu alkohol $70 \%$.

Kupu-kupu diamati, ditangkap, di identifikasi dan segera di lepaskan pada lokasi tangkapan ke alam jika spesies tersebut sama. Penangkapan kupu-kupu dengan menggunakan jaring kupu-kupu dengan membentuk angka delapan sehingga kupu-kupu yang masuk kedalam jaring tidak dapat keluar. Kupu-kupu yang terkoleksi menggunakan insect net dicatat untuk setiap jenisnya yang sudah diketahui dan dihitung kelimpahannya, kemudian dicatat faktor lingkungannya. Identifikasi spesimen dilakukan di lingkungan Perumahan Bukit Kalibagor 
Indah berdasarkan Indentification guide for butterflies of west java Famili Papilionidae, Pieridae and Nymphalidae (Schulze, 2007).

\section{Hasil dan Pembahasan}

\subsection{Karakteristik Lokasi Penelitian dan Waktu Pengambilan Sampel}

Lokasi pengambilan sampel di lingkungan Perumahan Bukit Kalibagor Indah, Kecamatan Kalibagor, Kabupaten Banyumas. Provinsi Jawa Tengah. Pengambilan sampel dilakukan pada bulan April- bulan Mei 2021, pada pukul 08.00-12.00 WIB.

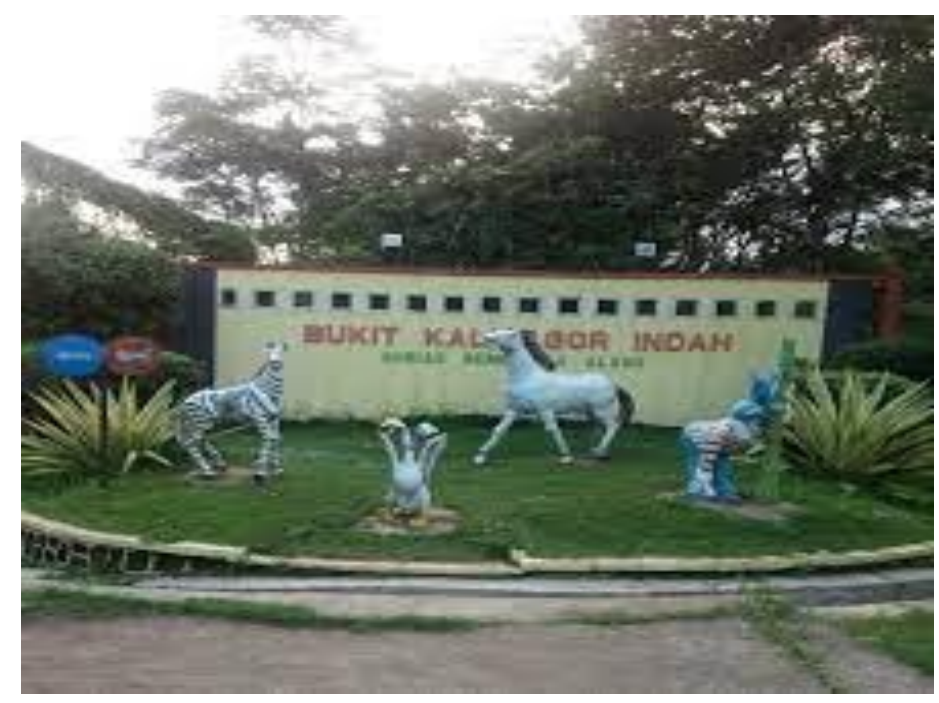

Gambar 1. Lokasi pengambilan sampel kupu-kupu di lingkungan Perumahan Bukit Kalibagor Indah

\subsection{Kupu-kupu Di Lingkungan Perumahan Bukit Kalibagor Indah}

Tabel 1. Jenis-jenis Kupu-kupu di Perumahan Bukit Kalibagor Indah

\begin{tabular}{|c|c|c|c|}
\hline & & & Jumlah \\
\hline Famili & Genus & Spesies & Individu \\
\hline \multirow[t]{3}{*}{ Nymphalidae } & Amatusia & Amathusia taenia-taenia (Schulze, 2007) & 3 \\
\hline & Euploea & Euploea modesta (Schulze, 2007) & 3 \\
\hline & & Euploea mulciber basillissa (Cramer,1777) & 2 \\
\hline \multirow[t]{7}{*}{ Pieridae } & Appias & Appias albina-albina (Schulze, 2007) & 7 \\
\hline & & Appias paulina (Schulze, 2007) & 9 \\
\hline & & Appias indra lucas (Schulze, 2007) & 1 \\
\hline & Catopsilia & Catopsilia piranthe-piranthe (Schulze, 2007) & 5 \\
\hline & & Catopsilia pomona (Schulze, 2007) & 6 \\
\hline & Leptosia & Leptosia nina chlorographa (Schulze, 2007) & 8 \\
\hline & Saletara & Saletara liberia panda (Schulze, 2007) & 4 \\
\hline
\end{tabular}


Penelitian di Perumahan Bukit Kalibagor Indah ditemukan 10 spesies dengan 6 genus dari 48 individu (Tabel 1) yang termasuk ke dalam 2 famili, yaitu Nympalidae (2 spesies) dan Pieridae (8 spesies). Jumlah spesies yang ditemukan lebih sedikit dibandingkan dengan hasil penelitian Sugiarto (2019) yang menemukan 40 spesies kupu-kupu di Desa Serdang Menang, Kecamatan Sirah Pulau Padang, Kabupaten Ogan Komering Ilir, Sumatera Selatan. Kupu-kupu yang ditemukan terdiri dari dari 26 genus, dan 5 famili : spesies kupu-kupu dari famili Nymphalidae mendominasi dengan jumlah spesies 16, Pieridae 8 spesies, Papilionidae 7 spesies, Hesperiidae 6 spesies, dan Lycanidae 3 spesies. Papilio paling banyak dengan 5 spesies, Junonia dengan 4 spesies, dan Catopsilia dengan 3 spesies. Hal ini diperkirakan karena tersedianya vegetasi untuk mendukung habitat dan makanan bagi kupu-kupu masih sedikit. Menurut Syafitri et al., (2010), bahwa kupu-kupu sangat tergantung pada tipe vegetasi sebagai sumber pakan dan apabila vegetasi tidak mendukung maka kupu-kupu akan berpindah ke daerah baru yang banyak terdapat vegetasi sebagai sumber pakan. Dibandingkan dengan hasil penelitian Kurniawan, et al., (2020) di Habitat Eko-wisata Taman Bunga Merangin Garden Bangko Jambi, ditemukan sebanyak 3 famili dari 16 jenis spesies. Jumlah famili dan spesiesnya lebih banyak dibanding hasil penelitian kupu-kupu di lingkungan Perumahan Bukit Kalibagor Indah. Spesies yang mendominasi adalah Junonia orithya dengan jumlah individu sebanyak 88 individu.

Sedangkan dengan hasil penelitian Amanda (2019) di Perumahan Citra Grand City Kota Palembang memiliki kesamaan yang sama yaitu menemukan spesies kupu-kupu Leptosia nina. Hal ini dikarenakan kupu-kupu Leptosia nina memiliki penerbangan yang lemah dan tidak menentu serta tubuh kupu-kupu itu bergerak naik turun saat mengepakkan sayapnya. Leptosia nina juga terbang rendah di atas rerumputan dan jarang meninggalkan permukaan tanah (Mrkku, 2021).

Jumlah spesies dan jumlah individu yang paling banyak ditemukan adalah famili Pieridae di ikuti dari famili Nympalidae. Hal ini dikarenakan kupu-kupu famili Pieridae banyak ditemukan di sekitar tanaman hias perumahan. Menurut Roland (2006) menyatakan bahwa kelompok Pieridae sebagai polinator pada tanaman hias, lebih aktif dan lebih lama hinggap di pagi hari dan cenderung memiliki pakan pada tumbuhan familia Cappmaceae dan Asteraceae. Otsuka (2001) menambahkan bahwa tumbuhan dari famili Capparidaceae, Fabaceae, dan Loranthaceae merupakan tumbuhan inang utama bagi famili Pieridae. Kupu-kupu dari famili Pieridae kebanyakan tersebar di daerah tropis seperti Indonesia. Orr dan Kitching (2010), Pieridae dengan total 1.275 spesies tersebar di dunia, terutama di Indo-Australia. Persebaran individu mulai hutan hujan dataran rendah hingga padang rumput.

Genus kupu-kupu dari famili Pieridae yang ditemukan dilokasi penelitian sebanyak 4 genus. Adapun 4 genus tersebut adalah Appias, Catopsilia, Leptosia dan Saletara. Menurut Suwarno et al., (1987) dalam Dewi et al., (2012) famili Pieridae bersifat kosmopolitan dan tersedianya berbagai macam jenis tumbuhan menjadi sumber makanannya. Sifat kosmopolitan inilah yang menjadikan individu dan spesies dari famili Pieridae banyak ditemukan dalam lokasi penelitian. 


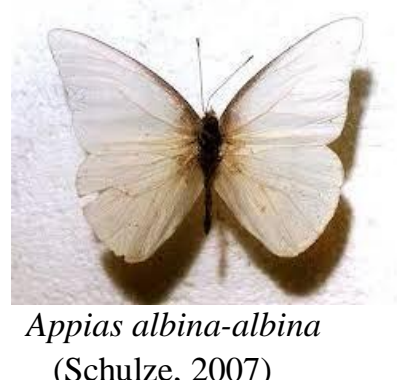

(Schulze, 2007)

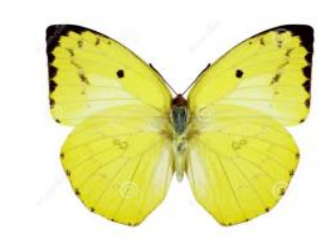

Catopsilia pomona

(Schulze, 2007)

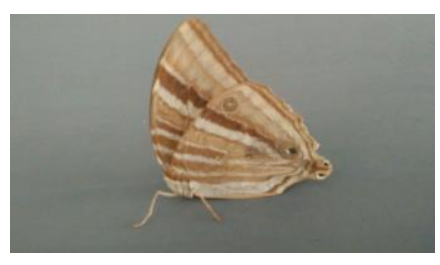

Amathusia taenia-taenia

(Schulze, 2007)

Gambar 1. Contoh jenis kupu-kupu mewakili 2 famili yang ditemukan

Spesies dari famili Pieridae yang paling banyak dijumpai di lokasi penelitian adalah Catopsilia pomona dengan jumlah spesimen yang ditemukan berjumlah 43 spesimen. Hal ini dikarenakan Catopsilia pomona (famili Pieridae) bersifat kosmopolitan (sebarannya sangat luas dan mudah beradaptasi dengan berbagai lingkungan). Selain itu, kupu-kupu ini juga hidup berkelompok serta memiliki kemampuan bermanuver dengan cepat saat terbang.

Genus kupu-kupu dari famili Nymphalidae berjumlah 2 yaitu Amatusia dan Euploea. Menurut Peggy dan Amir (2006), sumber pakan kupu-kupu famili Nymphalidae adalah famili Annonaceae, Leguminoceae, Composite, dan Poaceae. Dendang (2008), menambahkan bahwa tanaman inang dari famili Nymphalidae yaitu Annonaceae, Asteraceae, Moraceae, Rubiaceae, dan Anacardiaceae. Selain itu, bahwa famili Nymphalidae umumnya mempunyai penyebaran yang luas, menyukai tempat yang terang, daerah kebun, hutan dan juga menyukai buah yang busuk. Kupu-kupu dari famili Nymphalidae memiliki sifat terbang kuat, aktif dan cepat (Dalem dan Joni, 2017) serta kupu-kupu dari famili Nymphalidae cenderung bersifat polifag (mempunyai jenis makanan lebih dari satu macam), sifat inilah yang memungkinkan Nymphalidae tetap dapat memenuhi kebutuhannya akan tumbuhan inang meskipun tumbuhan inang utamanya tidak tersedia (Lestari et al., 2015).

Cleary dan Genner dalam Efendi (2009) dan Dennis et al., (2004) menyatakan bahwa banyaknya kupu-kupu pada suatu daerah dipengaruhi oleh penyebaran dan banyaknya tumbuhan pakan. Dimana, keberadaan kupu-kupu sangat bergantung pada tumbuhan pakannya, baik sebagai inang bagi larva maupun sebagai sumber nektar bagi imago (Rahayu dan Adi 2012). Menurut Patton (1963) dalam Hervina et al., (2016), jenis tumbuhan inang yang menjadi makanan larva kupu-kupu berbeda antara jenis kupu yang satu dengan lainnya, karena mempunyai kandungan kimia yang cocok untuk perkembangan larvanya.

Klasifikasi dari setiap spesimen yang diperoleh diuraikan sebagai berikut:

Klasifikasi

Kingdom: Hewan

Divisi: Arthropoda

Kelas: Serangga

Ordo: Lepidoptera
Klasifikasi

Hewan

Arthropoda

Serangga

Lepidoptera 
JURNAL KRIDATAMA SAINS DAN TEKNOLOGI

Data Jenis-jenis Kupu-kupu Di Lingkungan Perumahan Bukit Kalibagor Indah, Kecamatan Kalibagor

Vol. 03 No.02 2021

E-ISSN: 2685-6921

Universitas Ma'arif Nahdlatul Ulama Kebumen

Famili: Nymphalidae

Nymphalidae

Genus: $\quad$ Amathusia (Fabricius, 1807)

Euploea

Spesies: $\quad$ Amathusia taenia-taenia (Schulze, 2007)

Euploea modesta (Schulze, 2007)

Amathusia adalah genus kupu - kupu hutan besar dengan "ekor sayap" dalam keluarga Nymphalidae. Kupu-kupu ini dikenal sebagai palmkings dan larva pemakan palem (Arecaceae). Amathusia keberadaannya berkisar dari kepulauan Andaman hingga Sulawesi (Anonim, 2021).

\begin{tabular}{lll} 
Klasifikasi & & Klasifikasi \\
\hline Kingdom: & Hewan & Hewan \\
\hline Divisi: & Arthropoda & Arthropoda \\
\hline Kelas: & Serangga & Serangga \\
\hline Ordo: & Lepidoptera & Lepidoptera \\
\hline Famili: & Nymphalidae & Nymphalidae \\
Genus: & Euploea & Appias \\
Spesies: & $\begin{array}{l}\text { Euploea mulciber (Cramer }, \\
\text { 1777) }\end{array}$ & Appias albina-albina (Schulze, 2007) \\
\hline
\end{tabular}

Sayap Euploea core memiliki sayap depan berbentuk segitiga, bagian apeks membulat, dan termen sedikit cekung dan rata. Sedangkan sayap belakang bentuknya membulat dan termen rata. Sayap bagian atas memiliki sayap depan berwarna dasar cokelat tua dengan empat bercak putih pada subapikal, tiga bercak putih besar pada submarginal dan bercak putih kecil pada marginal, sedangkan sayap belakang juga berwarna dasar cokelat tua dan terdapat bercak putih besar berjajar pada area postdiscal dan bercak putih kecil pada area marginal. Sayap bagian bawah berwarna dasar cokelat tua dengan motif yang sama dengan bagian atas, namun terdapat bercak putih kecil yang menyebar di sayap depan dan belakang. Tubuh bagian atas berwarna cokelat gelap, sedangkan bagian bawah berwarna hitam dengan bercak putih pada abdomen dan toraks (Rohman et al., 2019).

Sayap Appias olferna memiliki Sayap depan berbentuk segitiga, bagian apeks tumpul, termen lurus dan rata, sedangkan sayap belakang bentuknya bulat, dan termen rata. Sayap bagian atas memiliki sayap depan dan belakang berwarna putih, dengan warna hitam pada rangka sayap bagian apikal dan marginal, sedangkan sayap bagian bawah memiliki sayap depan dan belakang berwarna putih,namun pada sayap belakang terdapat bercak kuning pada pangkal costa. Tubuh bagian atas berwarna hitam dengan rambut putih, sedangkan tubuh bagian bawah berwarna putih (Rohman et al., 2019). 


\begin{tabular}{|c|c|c|}
\hline Klasifikasi & & Klasifikasi \\
\hline Kingdom: & Hewan & Hewan \\
\hline Divisi: & Arthropoda & Arthropoda \\
\hline Kelas: & Serangga & Serangga \\
\hline Ordo: & Lepidoptera & Lepidoptera \\
\hline Famili: & Nymphalidae & Nymphalidae \\
\hline Genus: & Appias & Appias \\
\hline Spesies: & $\begin{array}{l}\text { Appias paulina (Schulze, } \\
\text { 2007) }\end{array}$ & Appias indra lucas (Schulze, 2007) \\
\hline
\end{tabular}

\begin{tabular}{lll} 
Klasifikasi & & Klasifikasi \\
\hline Kingdom: & Hewan & Hewan \\
\hline Divisi: & Arthropoda & Arthropoda \\
\hline Kelas: & Serangga & Serangga \\
\hline Ordo: & Lepidoptera & Lepidoptera \\
\hline Famili: & Pieridae & Pieridae \\
\hline Genus: & Catopsilia & Catopsilia \\
\hline
\end{tabular}

Spesies: $\quad$ Catopsilia piranthe-piranthe Catopsilia pomona (Schulze, 2007) (Schulze, 2007)

Sayap Catopsilia scyla memiliki Sayap depan berbentuk segitiga, bagian apeks tumpul, dan termen lurus dan rata, sedangkan sayap belakang bentuknya bulat dan termen rata. Sayap bagian atas memiliki sayap depan berwarna putih dengan warna hitam pada area marginal dan apikal, sedangkan sayap belakang berwarna kuning tua dengan bintik hitam pada ujung rangka. Sayap bagian bawah berwarna oranye kekuningan dengan bercak-bercak berwarna oranye kecoklatan. Tubuh bagian atas berwarna hitam dengan rambut putih, sedangkan tubuh bagian bawah berwarna kuning (Rohman et al., 2019).

$\begin{array}{lll}\text { Klasifikasi } & \text { Klasifikasi } \\ \text { Kingdom: Hewan } & \text { Hewan }\end{array}$




\begin{tabular}{lll} 
Divisi: & Arthropoda & Arthropoda \\
\hline Kelas: & Serangga & Serangga \\
\hline Ordo: & Lepidoptera & Lepidoptera \\
Famili: & Nymphalidae & Nymphalidae \\
Genus: & Leptosia & Saletara
\end{tabular}

Spesies: $\quad$ Leptosia nina chlorographa Saletara liberia panda (Schulze, 2007) (Schulze, 2007)

Leptosia nina sangat mudah diidentifikasi karena memiliki ciri-ciri yang sangat mencolok dan berbeda dibanding kupu-kupu lainnya, bahkan dengan kupu-kupu member familia Pieridae sekalipun. Tubuhnya yang mungil (sekitar $25-35 \mathrm{~mm}$ ), sayap putih yang sisi luarnya bercorak coklat atau kehitaman dengan motif bercak-bercak tak beraturan. Sayap bagian dalam (upper side) terdapat dua bundaran hitam tak beraturan laksana mata, serta dua sapuan warna hitam pada sudut sayap atasnya (Anonim, 2021). Saletara liberia adalah kupu - kupu dari famili Pieridae. Ini ditemukan di Indonesia, Filipina, Semenanjung Malaysia dan berbagai pulau di wilayah tersebut. Subspesies S. l. jauhi dikenal dengan nama umum albatros Malaysia.

Beberapa tumbuhan berbunga yang terdapat dilokasi penelitian misalnya bunga putri malu (Mimosa pudica), bunga kertas (Bougainvillea), bunga tapak dara (Geranium), mangga (Mangifera indica), beluntas (Pluchea indica), jambu biji (Psidium guajava), pepaya (Carica papaya). Tumbuhan inang merupakan tumbuhan yang digunakan sebagai pakan larva kupukupu. Distribusi dan kelimpahan sumber pakan larva merupakan salah satu faktor penting yang mempengaruhi kelangsungan hidup larva kupu-kupu (Achmad 2002). Semakin tinggi kelimpahannya, maka ketersediaan pakan larva semakin banyak pula. Distribusi pakan berpengaruh terhadap ketersediaan ruang dalam mencari pakan, dan sebaran jenis kupu-kupu. Tumbuhan penghasilkan nektar juga sangat mempengaruhi kelangsungan hidup imago kupukupu, karena makanan utamanya adalah nektar bunga. Semakin banyak cairan nektar yang tersedia, maka semakin banyak pula imago yang datang mengunjungi tempat tersebut.

Tabel 2. Hasil Pengukuran Faktor Lingkungan di Perumahan Bukit Kalibagor Indah

\begin{tabular}{cc}
\hline Faktor Lingkungan & Kisaran \\
\hline Temperatur & $28-30{ }^{\circ} \mathrm{C}$ \\
\hline Kelembaban & $75-80 \%$ \\
\hline
\end{tabular}

Temperatur di lingkungan Perumahan Bukit Kalibagor Indah antara $28-31{ }^{0} \mathrm{C}$. Menurut Sarma et al., (2012); Lodh dan Agarwala (2016) Indeks keanekaragaman juga dipengaruhi faktor abiotik seperti suhu, kelembaban udara serta intensitas cahaya yang sesuai dengan aktifitas kupu-kupu serta faktor jumlah jenis, jumlah individu masing-masing jenis dan total individu sehingga dapat berubah sesuai komposisi dan sebaran serta kelimpahan masingmasing jenis. Pada pagi hari kupu-kupu aktif beraktivitas mencari pakan serta bereproduksi 
sehingga pada saat tersebut banyak ditemukan jenis kupu-kupu yang beranekaragam. Faktor lingkungan yang sesuai untuk kupu-kupu beraktivitas terdapat pada suhu $28-30^{\circ} \mathrm{C}$. Kupu-kupu memerlukan kelembaban udara antara $64-94 \%$ dan suhu antara $30-35^{\circ} \mathrm{C}$ (Achmad, 2002).

\section{Kesimpulan}

Berdasarkan hasil yang telah diperoleh dapat disimpulkan bahwa spesies di lingkungan perumahan bukit kalibagor indah berjumlah 10 spesies dengan 6 genus dari 48 individu yang termasuk ke dalam 2 famili, yaitu Nympalidae ( 3 spesies) dan Pieridae (7 spesies).

\section{Daftar Pustaka}

Achmad A. (2002). Potensi dan sebaran kupu-Kupu di kawasan taman wisata alam Bantimurung. Dalam: Workshop Pengelolaan Kupu-kupu Berbasis Masyarakat. Bantimurung, 05 Juni 2002. On line at http://www.unhas.ac.id /.pdf. Diakses pada tanggal 24 Juli 2021.

Amanda, N. (2019). Komposisi ordo Lepidoptera di Perumahan Citra Grand City Kota Palembang dan sumbangannya pada pembelajaran biologi SMA. Skripsi. Fakultas Keguruan dan Ilmu Pendidikan Universitas Sriwijaya.

Amathusia (kupu-kupu). https://en.wikipedia.org/wiki/amathusia_(butterfly). Diakses pada tanggal 24 Juli 2021.

Apriyanti. (2004). Keanekaan kupu-Kupu di Cagar Alam dan Taman Wisata Alam Pananjung Pangandaran Jawa Barat Jurusan Biologi. Fakultas MIPA. UNPAD, Bandung.

Arumsari, D., K. Cahyani, V. B. Sandya., A. Purnomosidi dan M.Anand. (2013). Analisis tipologi lepidoptera berdasarkan observasi habitat di kawasan Hutan Lindung Nusakambangan, Cilacap, Jawa Tengah.

Awinda. (2012). Identifikasi kupu-kupu (Lepidoptera) di Kawasan PTPN XII (Persero) Banjarsari-Jember. (online): http://awinda.web.id/2012/09/identifika si-kupu-kupulepidoptera-di-kawasan- ptpn-xii-persero-banjarsari-jember- 2.aspx, Diakses tanggal 24 Juli 2021.

Dalem, A.A.G dan M. Joni. (2017). Jenis-jenis kupu-kupu yang ditemukan di kawasan pariwisata Ubud, Bali. Prosiding Seminar Nasional Sainstek 2017. 163-177.

Dendang B. (2008). Keragaman kupu-kupu di Resort Salabintana Taman Nasional Gunung Gede Pangrango, Jawa Barat. Jurnal Penelitian Hutan dan Konservasi Alam 4, (1), 25-36.

Dennis R.L.H, Hodgson J.G, Grenyer R, Shreeve T.G, dan Roy D.B. (2004). Host plant and butterfly biology. Do host-plant strategies drive butterfly status?. J Ecological Entomology 29, (1), 12-26.

Dewi, A.,W., J. Waluyo., dan W. Subchan. (2012). Identifikasi kupu-kupu (lepidoptera) di Kawasan PT. Perkebunan nusantara (PTPN) XII (PERSERO) Banjarsari Jember dan pemanfaatannya sebagai sumber belajar biologi SMA. Artikel Penelitian. Jurusan Pendidikan MIPA, Fakultas Ilmu Keguruan dan Pendidikn, Universitas Jember. 
Efendi MA. (2009). Keragaman kupu-kupu (lepidoptera: ditrysia) di kawasan hutan koridor taman nasional gunung halimun salak, Jawa Barat [Thesis]. Sekolah Pascasarjana IPB, Bogor.

Hervina, C., M.Sylvia, Annisa., H.Kasmara., N. Fitriani. (2016). Analisis Keanekaan Dan Kekerabatan Kupu-Kupu Cagar Alam Leuweung Sancang Berdasarkan Karakter Morfologi. Prosiding Seminar Nasional MIPA. 323-328.

Koneri, R dan Maabuat, P.V. (2016). Diversity of Butterflies (Lepidoptera) in ManemboNembo Wildlife Reserve, North Sulawesi, Indonesia. Pakistan Journal of Biological Sciences, 19 (5), 202-210.

Kurniawan, B., R. R. Apriani., dan S. Cahayu. (2020). Keanekaragaman Spesies Kupu-kupu (Lepidoptera) pada Habitat Eko-wisata Taman Bunga Merangin Garden Bangko Jambi. Al-Hayat: Journal of Biology and Applied Biology, 3, (1), 1-7.

Lamatoa, D.C, R Koneri, R Siahaan, dan P.V Maabuat. (2013). Populasi kupu-kupu (Lepidoptera ) di Pulau Mantehage, Sulawesi Utara. Jurnal Ilmiah Sains 13, (1), 52-56.

Leo, S., Avifah, N., Sasangka, A.N., dan Zahra, S. (2016). Butterflies of Baluran National Park, East Java, Indonesia. Pros Sem Nas Masy Biodiv Indon. 2, (2).

Leptosia nina chloroprapha, $\mathrm{Si}$ Kupu-kupu Kebon Jawa. https://bluepurplegarden.wordpress.com/2016/09/18/leptosia-nina-chlorographa-si-kupukupu-kebon-jawa/. Di akses pada tanggal 24 Juli 2021.

Lestrasi, D.F., Rizma, D.A.P., Muhammad, R., dan Atika, D.P. (2015). Keanekaragaman kupukupu (Insekta: Lepidoptera) di Wana Wisata Alas Bromo, BKPH Lawu Utara, Karanganyar, Jawa Tengah. Pros Sem Nas Masy Biodiv Indo. 1, (6), 1284-1288.

Lestari, V.C., T.S. Erawan., Melanie, H. Kasmara., dan W. Harmawan. (2018). Keanekaragaman jenis kupu-kupu Famili Nymphalidae dan Pieridae di kawasan Cirengganis dan Padang Rumput Cikamal Cagar Alam Pananjung Pangandaran. Jurnal Agrikultura. 29, (1), 1-8.

Lodh R, dan Agarwala, B.K. (2016). Rapid assessment of diversity and conservation of butterflies in Rowa Wildlif Sanctuary: An Indo-Bumesse hotspotTripura, N.E. India. Tropical Biology. 57, (2), 231-242.

Markku, S. "Leptosia nina (Fabricius, 1793)". Lepidoptera dan Beberapa Bentuk Kehidupan Lainnya . Diakses pada 19 Juli 2021.

Otsuka, K. (2001). A Field Guide to the Butterflies of Borneo and South East Asia. Hornbill booksAdivision of Iwase bookshop Sdn. Bhd, Malaysia.

Orr and Kitching. (2010). The Butterflies of Australia. Sydney: Jacana Books.

Rahmawati, F. (2017). Biodiversitas Kupu-kupu Di Taman Wisata Alam Pananjung, Pangandaran sebagai Acuan Dasar Penentuan Strategi Konservasi. Tesis. Fakultas Biologi Universitas Jenderal Soedirman, Purwokerto. 
Rahayu, S. E., dan Adi, B. (2012). Kelimpahan dan Keanekaragaman Species Kupu-kupu (Lepidoptera: Rhopalocera) pada Berbagai Tipe Habitat di Hutan Kota Muhammad Sabki Kota Jambi. Jurnal Biospecies, 5, (2), 40-48.

Rohman, F., M. A. Efendi., dan L. R. Andrini. (2019). Bioekologi Kupu-kupu. Universitas Negeri Malang.

Roland, J. (2006) Effect of melanism of alpine Colias nastes butterflies (Lepidoptera: Pieridae) on activity and predation. Canadian Entomologist, 138, 52-58.

Sarma K, Kumar A, Devi A, Mazumdar K, Krishna M, Mudoi P, dan Das N. (2012). Diversity and habitat association of butterfly species in Foothilss of Itanagar, Arunchal Paradesh, India. Zoology. 1, 67-77.

Schultze, C.H. (2007). Identification guide for butterflies of West Java. http://www.scribd.com/. Accesesed date: April 20, 2010.

Sugiarto, A. (2019). Data Terbaru Jenis-jenis Kupu-kupu Di Desa Serdang Menang. Kumpulan Artikel Insect Village , 2, (5), 40 - 43.

Syafitri, M., Untari D.R, Sari Jl, Ismail M.U, dan Arifin I. (2010). Keanekaragaman dan Sebaran Jenis Kupu-kupu (Lepidoptera) DI Resort Gunung Putri, Taman Nasional Gunung Gede Pangrango.Jurusan Biologi FMIPA Universitas Negeri Jakarta.

Widhiono I. (2015). Diversity and abundance of Java endemics butterfly (Lepidoptera: Rhopalocera) at Mount Slamet, Central Java. Biospecies 7 (2): 59-67.

Yanuar, A., Mun'im, A., Lagho, A.B.A., Syahdi, R.R., Rahmat, M., dan Suhartanto, H. (2011). Medicinal Plants Database and Three Dimensional Structure of the Chemical Compounds from Medicinal Plants in Indonesia. International Journal of Computer Science Issues, 8. 